\title{
Genotoxic Effect of Iron Oxide Nanoparticles Treated Tannery Effluent on Zebrafish Danio rerio
}

\author{
D. Tamilmathi and M. R. Rajan $\dagger$ \\ Department of Biology, The Gandhigram Rural Institute (Deemed to be University) Gandhigram-624 302, \\ Tamil Nadu, India \\ †Corresponding author: M.R. Rajan; mrrrajanbio@gmail.com
}

\section{Nat. Env. \& Poll. Tech. Website: www.neptjournal.com \\ Received: 07-04-2020 \\ Revised: $30-05-2020$ \\ Accepted: 03-06-2020 \\ Key Words: \\ Genotoxicity \\ Iron oxide nanoparticles \\ Tannery effluent \\ Zebrafish}

\begin{abstract}
The present study deals with the genotoxic effect of iron oxide nanoparticles treated tannery effluent on zebrafish Danio rerio. The chemical co-precipitation method was used for the synthesis of iron oxide nanoparticles which were characterized by SEM, EDAX, XRD, FTIR and VSM. Physico-chemical characteristics of tannery effluent were also estimated. Iron oxide nanoparticles were used as nanoadsorbents in reducing the toxic substances present in tannery effluent. Behavioural studies and genotoxic effect on zebrafish exposed to different concentrations of iron oxide nanoparticles treated tannery effluent and control (raw tannery effluent) were carried out. Biochemical composition such as protein, carbohydrate and lipid were estimated in the muscles and gills of zebrafish on $14^{\text {th }}$ day after exposure. SEM images of iron oxide nanoparticles were observed at $5 \mu \mathrm{m}$ and $10 \mu \mathrm{m}$ which were spherical. EDAX spectrum recorded on synthesized iron oxide nanoparticles was identified in 7 peaks. FT-IR spectrum of iron oxide nanoparticles was analysed in the range of $500-4000 \mathrm{~cm}^{-1}$ and spectral bands were observed. Physico-chemical parameters of treated tannery effluent were decreased as the different concentrations of iron oxide nanoparticles increased. 200, 225 and 250 ppm treated tannery effluent were selected for median lethal concentration. No mortality was found in both control and iron oxide nanoparticles treated tannery effluent. The number of micronuclei was increased with increasing concentration of iron oxide nanoparticles when compared to control. Biochemical characteristics such as protein, carbohydrate and lipid in muscle and gills of zebrafish were higher in $T_{2}(225 \mathrm{ppm})$ than control and other concentrations. From this, it can be concluded that iron oxide nanoparticles can be used as nano-adsorbent in treating tannery effluent for effective removal of toxic substances.
\end{abstract}

\section{INTRODUCTION}

One of the most serious environmental problems is the existence of hazardous and toxic pollutants in industrial wastewater because most of these wastewaters end up into the environment. The main source of freshwater pollution can be attributed to the discharge of untreated waste, dumping of industrial effluent and run-off from agricultural fields. Nowadays, there is continuously increasing worldwide concern for the development of wastewater treatment technologies. Different treatment technologies are available for the removal of toxic substances. Adsorption is considered as one of the most effective, efficient and economical methods for the removal of pollutants from wastewater. Among the different treatment methods, the utilization of nanoparticles for the removal of pollutants from industrial effluents has arisen as an attractive research direction. This is because, compared to bulk materials, nanomaterials based adsorbents possess much larger surface area, which can provide a greater number of active sites for adsorption. Some kinds of nanomaterials such as carbon nanotubes, manganese oxides, zinc oxide, titanium oxide and iron oxide have been used as nano-adsorbents in many studies and showed excellent adsorption capacity for various heavy metals including chromium. Multi-wall carbon nanotubes have high dispersion and adsorption ability to remove heavy metals in wastewater treatment. Among these nano-adsorbents, the use of iron oxide nanoparticles has been received much attention due to their unique properties and effective in adsorption of toxic substances and heavy metals in tannery effluent (Lkhagvadulam et al. 2017).

Embryonic and larval Danio rerio (zebrafish) is increasingly used as a toxicological model to conduct rapid in vivo tests and developmental toxicity assays; the zebrafish features high genetic homology to mammals, robust, phenotypes, and high-throughput genetic and chemical screening have made it a powerful tool to evaluate in vivo toxicity. Recent studies employing zebrafish as an experimental model, comparing it with other in vivo and in vitro models, presenting zebrafish as a potent vertebrate tool to evaluate drug toxicity and 
efficacy to facilitate more extensive, easy and comprehensive knowledge of new generation drugs (Caballero \& Candiracci 2018).

The application of genotoxicity biomarkers in organisms allows for the assessment of mutagenic hazards and the identification of the sources and fate of the contaminants. Micronucleus (MN) test is an index of accumulated genetic damage during the lifespan of the cells is one of the most suitable techniques to identify integrated response to the complex mixture of contaminants. The large majority of studies on the genotoxic effect of the polluted water environment have been carried out with the use of bivalves and fish. Haemocytes and gill cells are the target tissues most frequently considered for the $\mathrm{MN}$ determination in bivalves. The erythrocyte MN test in fishes was also widely and frequently applied for genotoxicity assessment of freshwater and marine environment in situ using native or caged animals following different periods of exposure (Bolognesi \& Hayashi 2011). The study related to the genotoxic effect of iron oxide nanoparticles treated tannery effluent on zebrafish Danio rerio is very important and required, hence the present investigation was made.

\section{MATERIALS AND METHODS}

\section{Materials}

Ferrous chloride $\left(\mathrm{FeCl}_{2}\right)$, ferric chloride $\left(\mathrm{FeCl}_{3}\right)$ and sodium hydroxide were used for the synthesis of the iron oxide nanoparticles $\left(\mathrm{Fe}_{3} \mathrm{O}_{4}\right)$ and purchased from Loba Chemicals, India. All the reagents used for the synthesis of $\mathrm{Fe}_{3} \mathrm{O}_{4}$ nanoparticles were of analytical grade and used without further purification. All the glassware were washed, rinsed with deionized water, dried and heat sterilized in a hot air oven.

\section{Methods}

\section{Synthesis of Iron Oxide Nanoparticles}

The co-precipitation method was used for the synthesis of iron oxide nanoparticles. The aqueous solution of $\mathrm{FeCl}_{2}$ and $\mathrm{FeCl}_{3}$ was prepared in 1:2 ratio and $\mathrm{NaOH}(0.1 \mathrm{~N})$ was added with constant stirring within 30 minutes, the solution gets brownish yellow colour. The $\mathrm{pH}$ of the solution was 1 . The aqueous solution with a further constant stirring, within 30 minutes a visible colour change was observed. The yellow colour aqueous solution turned into greenish-black precipitate and the $\mathrm{pH}$ was adjusted to 12 . After the precipitation, it was centrifuged at $500 \mathrm{rpm}$ within 3 minutes and added with ethanol in trace volume to collect the iron oxide nanoparticles which were allowed to air dry/dissolve in distilled water for $8 \mathrm{~h}$ sonication $(50 \mathrm{~Hz}$ frequency Vibronics $-230 \mathrm{~V})$.

\section{Characterization of Iron Oxide Nanoparticles}

(a) Scanning Electron Microscope (SEM): SEM analysis is a powerful investigative tool which uses a focused beam of electrons to produce complex, high magnification images of a sample's surface topography. Morphology of the sample $\left(\mathrm{Fe}_{3} \mathrm{O}_{4} \mathrm{NPs}\right)$ was investigated using a scanning electron microscope (SEM) (LEO 1455 VP).

(b) Energy Dispersive X-ray Spectroscopy (EDAX): A minute drop of nanoparticles solution was cast on aluminium foil and subsequently dried in the air before transferring it to the microscope. An energy dispersive X-ray detection instrument (EDAX) (HORIBA 8121-H) was used to examine the elemental composition of the sample.

(c) X-ray Diffraction (XRD): Structure and crystalline size of $\mathrm{Fe}_{3} \mathrm{O}_{4}$ nanoparticles were determined by using $\mathrm{XRD}$ diffractometer with nickel-filter $\mathrm{CuK} \alpha$ radiations in the 20 range $(\lambda=1.5418 \AA)$ from an $\mathrm{X}$-ray tube run at $40 \mathrm{kV}$ and $30 \mathrm{ma}$.

(d) Vibrating Sample Magnetometer (VSM): The magnetic property of $\mathrm{Fe}_{3} \mathrm{O}_{4}$ nanoparticles was determined by vibrating sample magnetometer.

\section{Collection and Acclimation of Fish}

For toxicity studies, zebrafish fingerlings $(3.5 \pm 1.5 \mathrm{~g})$ were collected from Aqua garden, Madurai and transported to the laboratory in polythene bags filled with oxygenated water. Fish were acclimated in round plastic troughs for 15 days at $28 \pm 2^{\circ} \mathrm{C}$. During acclimation, fish were fed with trainee feed containing fish meal, groundnut oil cake, wheat flour and rice bran in the form of dry pellets.

\section{Sample Collection (Tannery Effluent)}

Tannery effluent samples were collected in plastic containers from the discharged stream of tannery effluent situated in the central part of Dindigul town.

\section{Physico-Chemical Characteristics of Tannery Effluent}

The physico-chemical parameters such as colour, odour, $\mathrm{pH}$, electrical conductivity, total solids, total dissolved solids, total suspended solids, hardness, sodium, potassium, calcium, magnesium, sulphate, chloride, dissolved oxygen, dissolved carbon dioxide, BOD, COD and copper were estimated by standard methods (APHA 2012).

\section{Role of Iron Oxide Nanoparticles on Physico-Chemical Parameters of Tannery Effluent}

The role of iron oxide nanoparticles on the physico-chemical characteristics of tannery effluent was examined. Iron oxide nanoparticles were used as nano-adsorbents in treating tan- 
nery effluent with different concentrations such as 50ppm, 100ppm, 150ppm, 200ppm and 250ppm of $\mathrm{Fe}_{3} \mathrm{O}_{4} \mathrm{NPs}$.

\section{Acute Toxicity Tests ( $\mathrm{LC}_{50}$ Determination)}

Acute toxicity tests were conducted in this study following International Standard Guidelines (ASTM 1993). This study was conducted for 96 hours at room temperature. The raw tannery effluent was taken as a control. Different concentrations of iron oxide nanoparticles treated tannery effluent such as 200ppm, 225ppm and 250ppm were used for further studies. Ten fish were maintained in triplicates.

\section{Genotoxicity (Micronucleus Assay)}

Blood samples were taken from the fish in control and each concentration of iron oxide nanoparticles treated tannery effluent, smeared on clean glass slides and dried for $10 \mathrm{~min}$ utes for removal of water content, and fixed in ethanol for 10 minutes. Then, the slides were stained with Geisma stain $(3 \%)$. The slides were evaluated under a light microscope and erythrocytes were counted for each sample (Suganya et al. 2018).

\section{Collection of Organ Samples}

The organs such as muscle and gills were dissected from the fish in control and different concentrations of iron oxide nanoparticles treated tannery effluent on $1^{\text {st }}$ day, $7^{\text {th }}$ day and $14^{\text {th }}$ day and stored frozen for further investigation.

\section{Biochemical Characteristics}

Total protein was determined spectrophotometrically at 660nm based on Lowry's method (Lowry et al. 1951). Total carbohydrate was determined based on the Anthrone method (Carrol et al. 1956). Total lipid was estimated by the method of Barnes \& Blackstock (1973).

\section{RESULTS AND DISCUSSION}

$\mathrm{Fe}_{3} \mathrm{O}_{4}$ nanoparticles were synthesized by chemical co-precipitation method. Iron oxide nanoparticles can be syn- thesized through co-precipitation of $\mathrm{Fe}^{2+}$ and $\mathrm{Fe}^{3+}$ by the addition of a base. The size, shape and composition of iron oxide nanoparticles synthesized through chemical methods depend on the type of salt used, $\mathrm{Fe}^{2+}$ and $\mathrm{Fe}^{3+}$ ratio, $\mathrm{pH}$ and ionic strength (Ali et al. 2016). Complete precipitation of $\mathrm{Fe}_{3} \mathrm{O}_{4}$ should be expected between $\mathrm{pH} 9$ and 14 (Gupta $\&$ Wells 2004). The precipitated magnetite is black in colour. $\mathrm{Fe}_{3} \mathrm{O}_{4}$ produced are usually coated with organic or inorganic molecules during the precipitation process (Kim et al. 2001).

The morphology of the iron oxide nanoparticles was studied by scanning electron microscopy. It revealed the spherical and rectangular shapes of synthesized nanoparticles. It showed a clear image of highly dense iron oxide nanoparticles and micron-scale size range about $9.48 \mathrm{~mm}$ (scale bar at $10 \mu \mathrm{m}$ ) and $9.48 \mathrm{~mm}$ (scale bar at $5 \mu \mathrm{m}$ ) (Fig.1). Keerthika et al. (2017) reported that the iron oxide nanoparticles having micron-scale size range about $10.91 \mathrm{~mm}$ (scale bar $5 \mu \mathrm{m}$ ) and $10.86 \mathrm{~mm}$ (scale bar $10 \mu \mathrm{m}$ ). Hariani et al. (2013) reported that the SEM image of synthesized iron oxide nanoparticles have a clear image ranges from $30 \mathrm{~nm}$ to $100 \mathrm{~nm}$. Similar results on SEM analysis of iron oxide nanoparticles had also been reported by Lida et al. (2007).

The presence of carbon (C), oxygen (O) and iron (Fe) was revealed in synthesized nanoparticles by EDAX spectral analysis. EDAX spectrum recorded on the iron oxide nanoparticles is shown at three peaks located between $0.5 \mathrm{KeV}$ and $6.5 \mathrm{KeV}$. The two peaks of Fe element were located on the spectrum at $0.8 \mathrm{KeV}$ and $6.5 \mathrm{KeV}$ and another peak of $\mathrm{O}$ element was located on the at $0.5 \mathrm{KeV}$ (Fig. 2). Keerthika et al. (2017) reported the EDAX spectrum of iron oxide nanoparticles which showed three peaks located between $2 \mathrm{KeV}$ and $10 \mathrm{KeV}$ maxima related to the iron characterized lines $\mathrm{K}$.

The FTIR spectrum of iron oxide nanoparticles was analysed in the range of 400-4000 $\mathrm{cm}^{-1}$. Fourier Transform Infrared Spectroscopy revealed the functional groups of iron
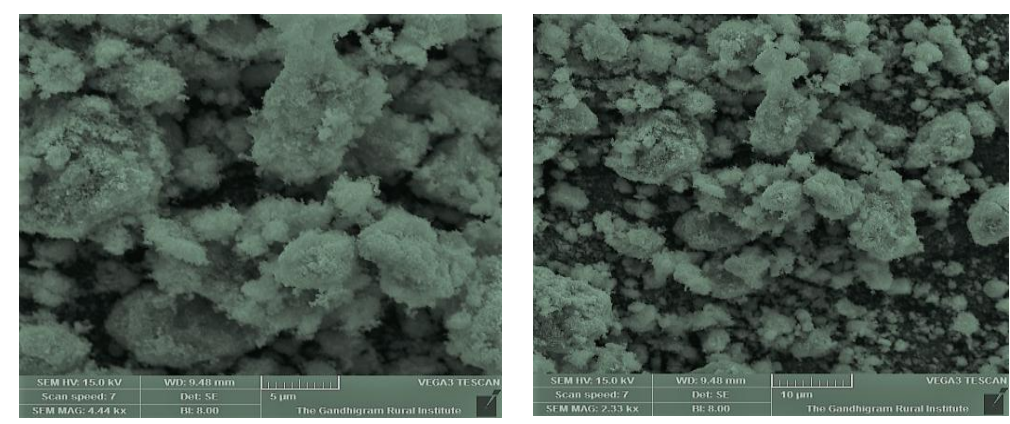

Fig. 1: SEM images of iron oxide nanoparticles. 


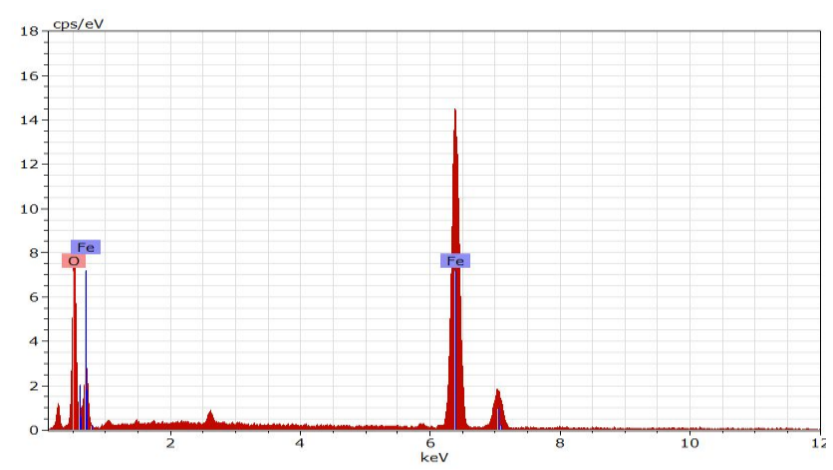

Fig. 2: EDAX image of iron oxide nanoparticles.

oxide nanoparticles and viewed the functional groups of alcohol, phenol, alkanes, ketones, saturated aliphatic, alkyl halides and $\mathrm{O}-\mathrm{H}, \mathrm{C}-\mathrm{H}, \mathrm{C}-\mathrm{Br}, \mathrm{C}=\mathrm{O}, \mathrm{C}-\mathrm{I}$ stretching of proteins (Fig. 3 and Table 1). Arokiyaraj et al. (2013) reported that the main functional groups of iron oxide nanoparticles are alcohol, phenols and primary amines. Similar results were obtained from the FT-IR spectrum of iron oxide nanoparticles confirmation peak at $511-535 \mathrm{~cm}^{-1}$ (El-Kassas Hala et al. 2016).

The XRD diffraction peaks indexed with crystal planes are $19.5^{\circ}(111), 30.02^{\circ}(220), 35.22^{\circ}(311), 54.08^{\circ}$ (422), $64.55^{\circ}(440)$ and $78.36^{\circ}(444)$. The samples were scanned between angles $0^{\circ}$ to $90^{\circ}$ to obtain the equatorial reflection. Structure and crystalline size of nanoparticles were determined by XRD with JCPDS Card No.89-2355 and 89-3854. The average crystalline size of chemically synthesized iron oxide nanoparticles was 15.58 and $21.34 \mathrm{~nm}$ (Fig. 4). Suganya et al. (2016) reported that the synthesized iron oxide nanoparticles are crystal in nature and further confirmed by XRD and the nano-crystal average size is 10 to $16 \mathrm{~nm}$. Wu et al. (2011) reported that XRD patterns of synthesized particles with the standard diffraction spectrum of the synthesized product are crystalline iron oxide. The

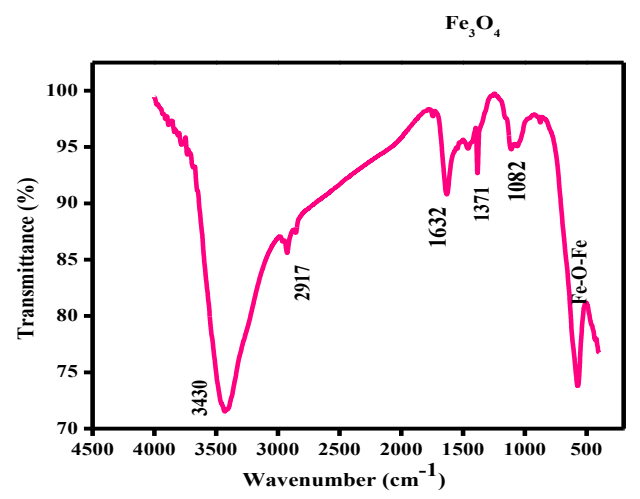

Fig. 3: FT-IR image o iron oxide nanoparticles. sharpness of XRD reflections indicates that the synthesized iron oxide is crystalline.

The magnetic properties of iron oxide nanoparticles were measured by Vibrating Sample Magnetometer (VSM) (Fig. 5). The synthesized iron oxide nanoparticles exhibit low saturation magnetization at $8.865 \mathrm{emu}^{-1} \mathrm{~g}^{-1}$ than the bulk $\mathrm{Fe}_{3} \mathrm{O}_{4}$. Similarly, Mahdavi et al. (2013) reported that all the nanoparticles exhibit superparamagnetic behaviour and have low saturation magnetization (Ms) values than the bulk $\mathrm{Fe}_{3} \mathrm{O}_{4}\left(92 \mathrm{emu}^{-1}\right)$. The saturation magnetization (Ms) of the $\mathrm{Fe}_{3} \mathrm{O}_{4}$ magnetic nanoparticles increase from 58.60 to 78.00 emu. $\mathrm{g}^{-1}$ with an increase of the nanoparticle sizes from 7.83 to $9.41 \mathrm{~nm}$. The result was due to the surface order or disorder interaction of the magnetic spin moment.

The physico-chemical characteristics of raw tannery effluent are presented in Table 2. All the parameters were higher than treated tannery effluent. Unpleasant odour of tannery effluent was due to microbial growth (Muthukkauppan \& Parthiban 2018). Very high EC is due to the higher concentration of acid-base and salt in water (Kataria et al. 1995). Also increase in BOD level is a reflection of microbial oxygen demand, leading to depletion of dissolved oxygen (Poole et al. 1977). Similarly, Rajan \&

Table 1: FT-IR functional group representation of iron oxide nanoparticles.

\begin{tabular}{|llll|}
\hline Bands & Functional groups & Type of vibration & Intensity \\
\hline 3439.42 & Alcohol, phenol & O-H stretch & Strong \\
2924.03 & Alkanes & C-H stretch & Medium \\
1631.00 & Ketones, saturated aliphatic & C=O stretch & Strong \\
1109.35 & Alkane & C-OH stretch & Strong \\
1026.90 & Alcohol group & C-F stretch & Strong \\
582.87 & Alkyl halides & C-Br stretch & Medium \\
479.70 & Alkyl halides & C-I stretch & Strong \\
\hline
\end{tabular}




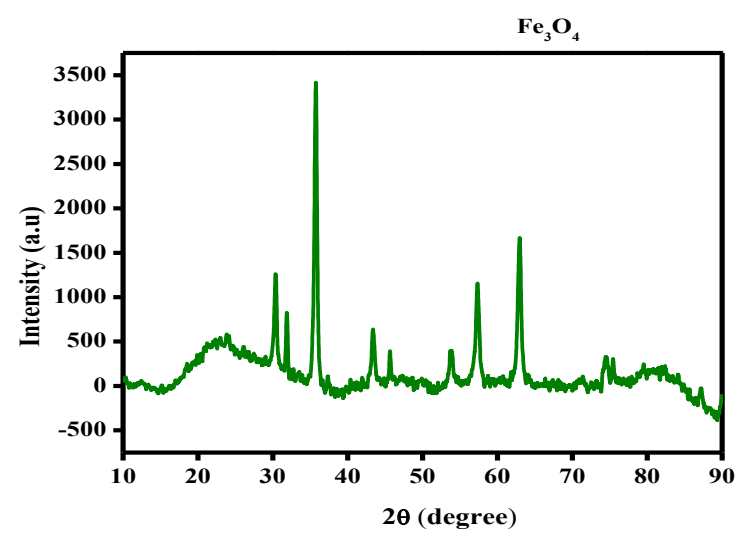

Fig. 4: XRD image of iro oxide nanoparticles.

Murali (2011) reported the physico-chemical characteristics of tannery effluent collected from a Common Tannery Effluent Treatment Plant located near Senkulam lake in Dindigul and treated with different leaves of plants for the removal of chloride. Lkhagvadulam et al. (2017) reported the use of maghemite nanoparticles for removal of $\mathrm{Cr}$ in tannery wastewater and maximum adsorption efficiency of total $\mathrm{Cr}$ was achieved $96.7 \%$ at an optimum condition and

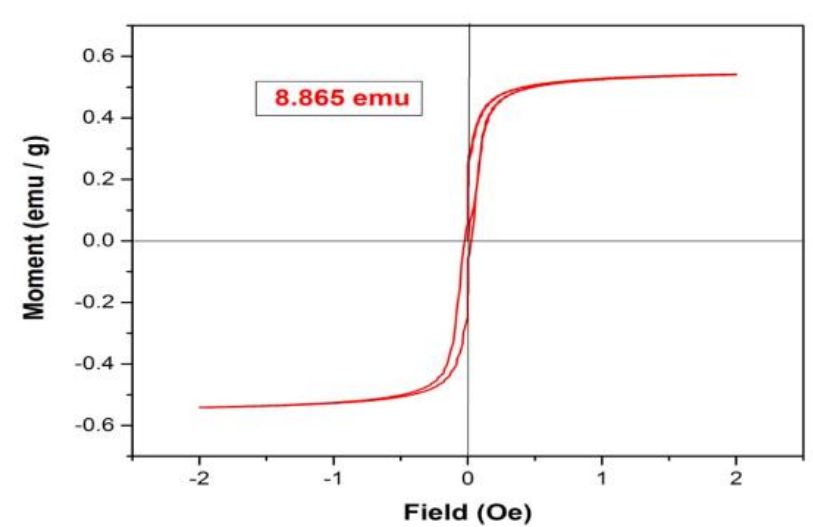

Fig. 5: VSM image of iron oxide nanoparticles.

also observed the best efficiency in removing major physicochemical parameters (TCr, SS, COD, sulphide and turbidity) in tannery wastewater.

Different concentrations of iron oxide nanoparticles (50ppm, 100ppm, 150ppm, 200ppm and $250 \mathrm{ppm}$ ) were used as nano-adsorbents in treating tannery effluent to reduce the physico-chemical contaminants (Table 3). The maximum adsorption efficiency of iron oxide nanoparticles

Table 2: Physico-chemical characteristics of tannery effluent.

\begin{tabular}{|c|c|c|c|}
\hline S. No. & Parameters & Units & Values \\
\hline 1. & Colour & - & Dark brown \\
\hline 2. & Odour & - & Unpleasant smell \\
\hline 3. & $\mathrm{pH}$ & - & 8.55 \\
\hline 4. & Electrical conductivity & $\mathrm{Ms} / \mathrm{cm}$ & 251.24 \\
\hline 5. & Total solids & $\mathrm{mg} / \mathrm{L}$ & 17444.4 \\
\hline 6. & Total dissolved solids & ", & 15190.4 \\
\hline 7. & Total suspended solids & ", & 2254 \\
\hline 8. & Total hardness & , & 5844.8 \\
\hline 9. & Sodium & , & 2760 \\
\hline 10. & Potassium & , & 63.96 \\
\hline 11. & Calcium & , & 1840 \\
\hline 12. & Magnesium & ", & 410.8 \\
\hline 13. & Sulphate & , & 62.12 \\
\hline 14. & Chloride & , & 4890.8 \\
\hline 15. & Dissolved oxygen & , & 3.39 \\
\hline 16. & Dissolved carbon dioxide & , & 25.2 \\
\hline 17. & BOD* & , & 1570 \\
\hline 18. & $\mathrm{COD}^{* *}$ & , & 21480 \\
\hline 19. & Nitrogen & , & 155 \\
\hline 20. & Copper & , & 0.016 \\
\hline
\end{tabular}

*Biological Oxygen Demand, **Chemical Oxygen Demand. All the values are an average of ten individual observations. 
Table 3: Physico-chemical characteristics of $\mathrm{Fe}_{3} \mathrm{O}_{4}$ NPs treated tannery effluent.

\begin{tabular}{|c|c|c|c|c|c|c|c|}
\hline \multirow[t]{2}{*}{ S.No. } & \multirow[t]{2}{*}{ Parameters } & \multirow[t]{2}{*}{ Unit } & \multicolumn{5}{|c|}{ Different concentration of iron oxide nanoparticles treated tannery effluent } \\
\hline & & & $50 \mathrm{ppm}$ & 100ppm & $150 \mathrm{ppm}$ & 200ppm & 250ppm \\
\hline 1. & Colour & - & Dark brown & Light brown & Light green & Light yellow & colourless \\
\hline 2. & Odour & - & - & - & - & - & - \\
\hline 3. & $\mathrm{pH}$ & - & 8.30 & 8.22 & 7.92 & 7.54 & 7.11 \\
\hline 4. & Electrical conductivity & $\mathrm{Ms} / \mathrm{cm}$ & 242.1 & 226.4 & 216.28 & 200,84 & 182.55 \\
\hline 5. & Total solids & $\mathrm{mg} / \mathrm{L}$ & 3433 & 3233 & 2933 & 2850 & 2833 \\
\hline 6. & Total dissolved solids & , & 2912 & 2780 & 2655 & 2624 & 2100 \\
\hline 7. & Total suspended solids & , & 521 & 300 & 278 & 226 & 100 \\
\hline 8. & Total hardness & , & 5200 & 4400 & 3200 & 2800 & 2000 \\
\hline 9. & Dissolved oxygen & , & 4.04 & 6.464 & 6.48 & 6.52 & 6.56 \\
\hline 10. & Dissolved carbon dioxide & , & 18 & 16 & 14 & 10 & 6 \\
\hline 11. & Chloride & , & 3834 & 3550 & 3266 & 2840 & 2414 \\
\hline 12. & Magnesium & , & 290 & 282 & 266 & 250 & 243 \\
\hline 13. & Sulphate & , & 59 & 55.6 & 54.54 & 54.25 & 53 \\
\hline 14. & BOD & , & 1433 & 734 & 406 & 118.2 & 80.8 \\
\hline 15. & COD & , & 20000 & 12800 & 11200 & 9600 & 5600 \\
\hline 16. & Nitrogen & , & 124 & 109 & 90 & 72 & 55 \\
\hline 17. & Sodium & ppm & 2752 & 2715.4 & 2533 & 2032 & 1667 \\
\hline 18. & Potassium & , & 63.82 & 63.70 & 54.04 & 43.12 & 36.606 \\
\hline 19. & calcium & , & 908 & 400 & 342 & 301 & 297.8 \\
\hline 20. & Copper & , & 0.004 & 0.003 & 0.003 & 0.002 & 0.001 \\
\hline
\end{tabular}

in treating tannery effluent was observed at low $\mathrm{pH}$ and high concentration of iron oxide nanoparticles (200 and 250 $\mathrm{ppm})$. With the increase of adsorbent dose, the reduction of physico-chemical parameters of tannery effluent increase due to the increased available binding sites in the nanocomposite for the complexation of metal ions (Saravanan et al. 2013). A faster initial removal rate was possible due to the availability of sufficient vacant adsorbing sites in the adsorbent (Sivakami et al. 2013).

No mortality was found in both control and different concentrations of iron oxide nanoparticles for $\mathrm{LC}_{50}$ determination. The behavioural response gives a direct response of the animals to the pollutant. Observation of basic behavioural responses of zebrafish was made which showed jerking movement and breathing in water surface (Table 4). Suganthi et al. (2015) reported the behaviour patterns such as jerky movements, continuous opercular movement, and reduction in dorsal and anal fin movements in O.mossambicus treated with ZnO NPs. Sivakumar et al. (2014) evaluated the behavioural responses of Danio rerio exposed to raw tannery effluent which showed rapid swim with random movements and coughing due to inconvenience in breathing.
Micronucleus assay was done on $1^{\text {st }}, 7^{\text {th }}$ and $14^{\text {th }}$ day (Table 5). Micronuclei in erythrocytes of zebrafish increases with increasing concentrations of iron oxide nanoparticles treated tannery effluent when compared to the control group. The number of micronuclei present in different concentrations of iron oxide nanoparticles treated tannery effluent differ significantly from the control group at $(\mathrm{P}$ $<0.001)$ on $1^{\text {st }}$ day, $(\mathrm{P}<0.01)$ on $7^{\text {th }}$ and $14^{\text {th }}$ day based

Table 4: Basic observation of zebrafish exposed to control and iron oxide nanoparticles treated tannery effluent.

\begin{tabular}{|lll|}
\hline S.No. & Activity & Observation \\
\hline 1 & Circular swimming & Yes \\
2 & Jerk movement & Yes \\
3 & Bottom resting & No \\
4 & Surface respiration & Yes \\
5 & Aggressive movement & Yes \\
6 & Excess of mucous secretion & No \\
7 & Mortality observation & Yes \\
8 & Behaviour observation & Yes \\
9 & Breathing movement & Surface \\
\hline
\end{tabular}


Table 5: Micronucleus Assay.

\begin{tabular}{|llll|}
\hline Treatments & $\begin{array}{l}\text { Micronuclei } \\
0^{\text {th }} \text { day }\end{array}$ & $\begin{array}{l}\text { Micronuclei } \\
7^{\text {th }} \text { day }\end{array}$ & $\begin{array}{l}\text { Micronuclei } \\
14^{\text {th }} \text { day }\end{array}$ \\
\hline $\mathrm{T}_{0}$ & 3 & 13 & 18 \\
$\mathrm{~T}_{1}$ & $7^{* *}$ & $15^{*}$ & $25^{*}$ \\
$\mathrm{~T}_{2}$ & $9 * *$ & $18^{*}$ & $30^{*}$ \\
$\mathrm{~T}_{3}$ & $10^{* *}$ & $20^{*}$ & $31^{*}$ \\
\hline
\end{tabular}

Significantly different from the control group at $* * \mathrm{P}<0.001$ and $* \mathrm{P}<$ 0.01 based on $t$-test.

on $t$-test. Similarly, Suganya et al. (2018) reported the increased amounts of micronuclei with increasing of the concentration of iron oxide nanoparticles when compared to control group and less amount of micronuclei with a lower concentration of iron oxide nanoparticles. The micronucleus (MN) test in fish erythrocytes been has been successfully applied for the in situ detection of mutagenicity in a polluted environment and a significant increase in MN frequency in erythrocytes of fish collected in polluted marine or freshwater environments (Gustavino et al. 2001).

Biochemical characteristics such as protein, carbohydrate and lipid in zebrafish are higher in $\mathrm{T}_{2}(225 \mathrm{ppm}$ iron oxide nanoparticles treated tannery effluent) when compared to control (raw tannery effluent) and $\mathrm{T}_{1}(200 \mathrm{ppm}$ iron oxide nanoparticles treated tannery effluent) and $\mathrm{T}_{2}(250 \mathrm{ppm}$ iron oxide nanoparticles treated tannery effluent) (Figs. $6,7 \&$

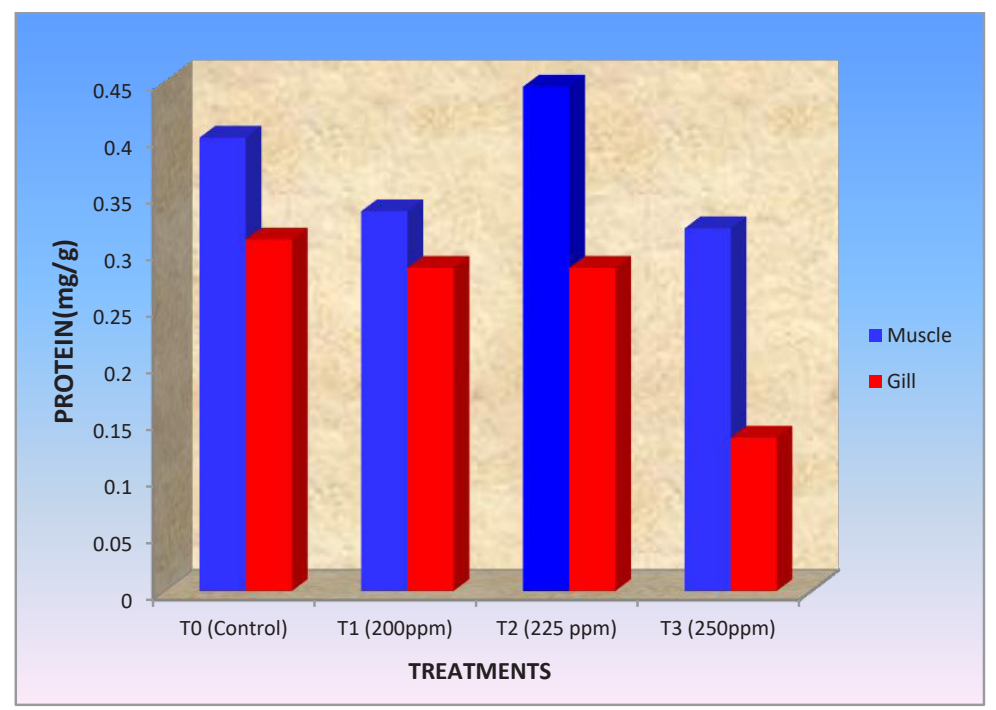

Fig. 6: Total protein level in muscle and gill of zebrafish on $14^{\text {th }}$ day.

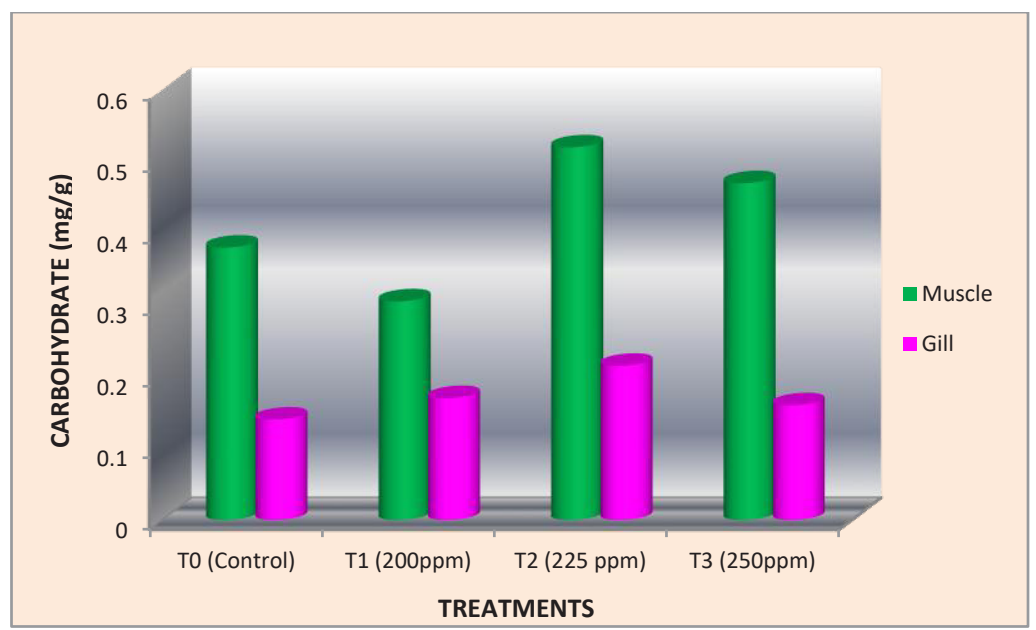

Fig. 7: Total carbohydrate level in muscle and gill in zebrafish on $14^{\text {th }}$ day. 


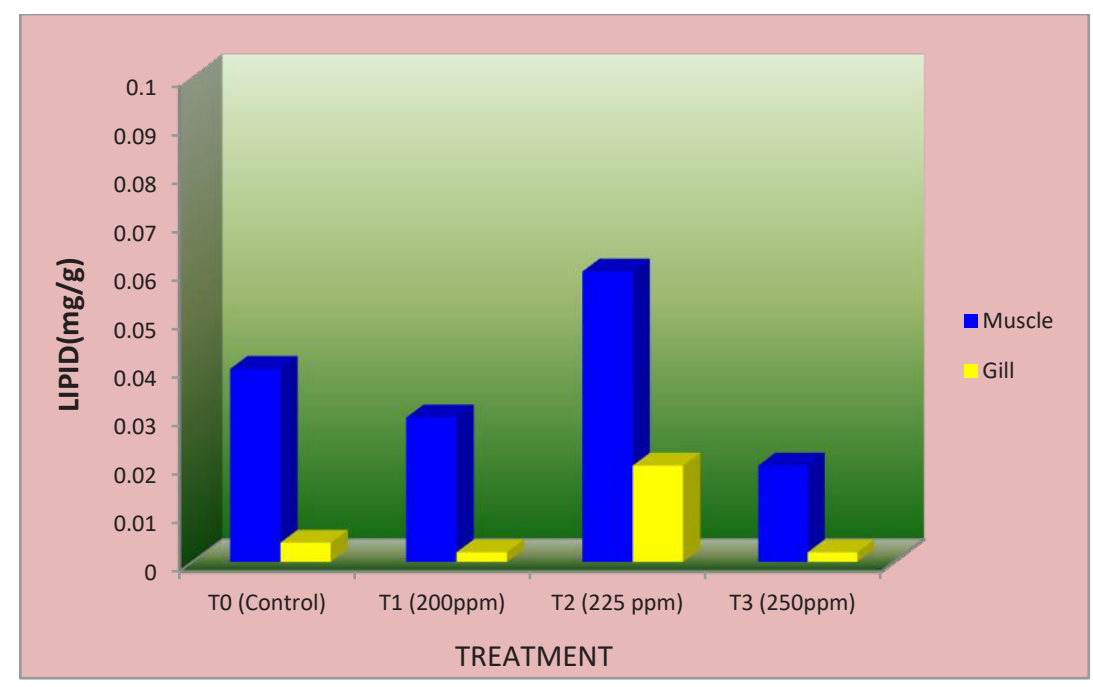

Fig. 8: Total lipid level in muscle and gill of zebrafish on $14^{\text {th }}$ day.

8). The biochemical mechanisms in an organism play an important role during stress conditions due to the presence of toxicants in aquatic ecosystems. Thangam (2014) reported that pollutants in the aquatic media cause effects on fishes at a cellular or molecular level which results in significant changes in biochemical characteristics. Zhu et al. (2009) studied that the interaction of nanoparticles with chemical or biological systems may lead to biochemical disturbances or adaptive responses and these responses can be used to assess the health conditions of aquatic organisms. Keerthika et al. (2017) reported that the iron oxide nanoparticles altered the biochemical characteristics of Labeo rohita. Sivakumar et al. (2015) similarly reported that the biochemical parameters of muscle, gill and liver of zebrafish Danio rerio decrease significantly from control when exposed to raw tannery effluent. Palaniappan \& Vijayasundaram (2008) reported that the arsenic intoxication induces significant alteration in the major biochemical composition of muscle proteins due to arsenic intoxication.

\section{CONCLUSION}

From this study, it is concluded that iron oxide nanoparticles can be used as nano-adsorbent in treating tannery effluent for effective removal of toxic substances.

\section{ACKNOWLEDGMENT}

The authors thank the Department of Biology, The Gandhigram Rural Institute (Deemed to be University) Gandhigram for offering facilities to carry out this study.

\section{REFERENCES}

Ali, A., Zafer, H., Zia, M., Hag, I.U., Phull, A.R., Ali, J.S. and Hussain, A. 2016. Synthesis, characterization, applications and challenges of iron oxide nanoparticles. Nanotechnol. Sci. Appl., 9: 49-67. doi: 10.2147/ NSA.S99986.

APHA, AWWA, WEF 2012. Standard Methods for Examination of Water and Wastewater. 22 $2^{\text {nd }}$ ed., American Public Health Association, Washington DC, USA.

Arokiyaraj, S., Saravanan, M., Udaya Prakash, N.K., Valan Arasu, M., Vijayakumar, B. and Vincent, S. 2013. Enhanced antibacterial activity of iron oxide magnetic nanoparticles treated with Argemone mexicana $\mathbf{L}$. leaf extract: An in vitro study. Materials Research Bulletin, 48: 3323-3327.

ASTM 1993. Standard practice for conducting acute tests with fishes, macroinvertebrates and amphibians. Designation E 729-88. ASTM Standards on Aquatic Toxicology and Hazards Evaluation, pp. 102-121.

Barnes, H. and Blackstock, J. 1973. Estimation of lipids in marine animals and tissues detailed investigation of the sulphophosphovanillin method for total lipids. J. Exp. Mor. Bio. Ecol., 12: 103-118.

Bolognesi, C. and Hayashi, M. 2011. Micronucleus assay in aquatic animals. Mutagenesis, 26(1): 205-213.

Caballero, M.V. and Candiracci, M. 2018. Zebrafish as screening model for detecting toxicity and drugs efficacy. JUMD Journal, doi. org/10.20517/2572-8180.2017.15.

Carrol, N.V., Longly, R.W. and Roe, J.H. 1956. Glycogen determination in liver and muscle by the use of anthrone reagent. J. Biol. Chem., 220: 583-593.

El-Kassas Hala, Y., Aly-Eldeen Mohamed, A. and Gharib Samiha, M. 2016. Green synthesis of iron oxide $\left(\mathrm{Fe}_{3} \mathrm{O}_{4}\right)$ nanoparticles using two selected brown seaweeds: Characterization and application for lead bioremediation. National Institute of Oceanography and Fisheries, 35(8): 89-98.

Gupta, A.K. and Wells, S. 2004. Surface modified superparamagnetic nanoparticles for drug delivery: Preparation, characterisation and cytotoxicity studies. Institute of Electrical and Electronics Engineers Transactions on Nanobioscience, 3(1): 66-73. 
Gustavino, B., Scornajenghi, K.A., Minissi, S. and Ciccotti, E. 2001. Micronuclei induced in erythrocytes of Cyprinus carpio (Teleostei, Pisces) by X-rays and colchicines. Genetic Toxicology and Environmental Mutagenesis, 494: 151-159.

Hariani, P.L., Faizal, M., Ridwan, R., Marsi, M. and Setiabudidaya, D. 2013. Synthesis and properties of $\mathrm{Fe}_{3} \mathrm{O}_{4}$ nanoparticles by coprecipitation method to removal procion dye. International Journal of Environmental Science and Development, 4(3): 336-340.

Kataria, H.O. and Jain, O.P.1995. Physico-chemical analysis of river Ajnar. Indian Journal of Environmental Protection, 12(9): 6467.

Keerthika, V., Ramesh, R. and Rajan, M.R. 2017. Toxicity assessment of iron oxide nanoparticles in Labeo rohita. International Journal of Fisheries and Aquatic Studies, 5(4): 01-06.

Kim, D.K., Zhang, Y., Voit, W., Rao, K.W. and Muhammed, M. 2001. Synthesis and characterization of surfactant-coated superparamagnetic monodispersed iron oxide nanoparticles. Journal of Magnetism and Magnetic Materials, 225(1): 30-36.

Lida, H., Takayanagi, K., Nakanishi, T. and Osaka, T. 2007. Synthesis of $\mathrm{Fe}_{3} \mathrm{O}_{4}$ nanoparticles with various sizes and magnetic properties by controlled hydrolysis. Journal of Colloid and Interface Science, 314(1): 274-280.

Lkhagvadulam, B., Tsagaantsetseg, B., Tergel, D. and Chuluunkhuyag, S. 2017. Removal of chromium from a tannery wastewater by using a maghemite nanoparticles. International Journal of Environmental Science and Development, 8(10): 696-702.

Lowry, O.H., Rosebrough, N.J., Lewis Farr, A. and Randall, R.J. 1951. Protein measurement with the Folin phenol reagent. Journal of Biological Chemistry, 193: 265-275.

Mahdavi, M., Ahmad, M.B., Haron, M.J., Namvar, F., Nadi, B., Rahman, M.Z.A. and Amin, J. 2013. Synthesis, surface modification and characterization of biocompatible magnetic iron oxide nanoparticles for biomedical applications. Molecules, 18: 7533-7548.

Murthy, B.N. and Ramarao, K.V. 1983. Ethology of fish Tilapia mossambica under lindane toxicity. Geobios, 10: 230-231.

Muthukkauppan, M. and Parthiban, P. 2018. A study on the physicochemical characteristics of tannery effluent collected from Chennai. International Research Journal of Engineering and Technology (IRJET), 5(3): 24-28.

Palaniappan, PL.RM. and Vijayasundaram, V. 2008. Fourier transform infrared study of protein secondary structural changes in the muscle of Labeo rohita due to arsenic intoxication. Food and Chemical Toxicology, 46: 389-396.

Poole, N.J., Wildish, D.J., Kristmanson, D.D. and Waldichuk, M.
1977. The effects of the pulp and paper industry on the aquatic environment. Critical Reviews in Environmental Science and Technology, 8(1-4): 153-195.

Rajan, M.R. and Murali, S.R. 2011. Dechloridation of treated tannery effluent using leaves of plants. Nature Environment and Pollution Technology, 4: 573-578.

Saravanan, D., Gomathi, T. and Sudha, P.N. 2013. Sorption studies on heavy metal removal using chitin/bentonite biocomposite. International Journal of Biological Macromolecules, 53: 67-71.

Sivakami, M.S., Gomathi, T., Venkatesan, J., Jeong, H.S., Kim, S.K. and Sudha, P.N. 2013. Preparation and characterization of nanochitosan for treatment. International Journal of Biological Macromolecules, 57: 204-212.

Sivakumar, P., Kanagappan, M. and Sam Manohar Das 2015. Flux of tissue substrates in Danio rerio exposed to raw tannery effluent. International Journal of Engineering Research and General Science, 3(6): 496-502.

Sivakumar, P., Kanagappan, M. and Sam Manohar Das, S. 2014. Toxicity evaluation and behavioral responses of Danio rerio exposed to raw tannery effluent. Journal of Entomology and Zoology Studies, 2(6): 288-291.

Suganthi, P., Murali, M., Sadiq Bukhari, A., Syed Mohamed, H.E., Basu, H. and Singhal, R.K. 2015. Behavioral and histological variations in Oreochromis mossambicus after exposure to $\mathrm{ZnO}$ nanoparticles. International Journal of Applied Research, 1(8): 524-531.

Suganya, D., Rajan, M.R. and Ramesh, R. 2016. Green synthesis of iron oxide nanoparticles from leaf extract of Passiflora foetida and its antibacterial activity. International Journal of Current Research, 8(11): 08142-42085.

Suganya, D., Ramakritinan, C. M. and Rajan, M.R. 2018. Adverse effects of genotoxicity, bioaccumulation and ionoregulatory modulation of two differently synthesized iron oxide nanoparticles on zebrafish (Danio rerio). Journal of Inorganic and Organometallic Polymers and Materials, 28(6): 2603-2611. doi:10.1007/s10904-018-0935-3.

Thangam, Y. 2014. Effect of nitrite toxicity in carbohydrate metabolism to freshwater fish Cirrhinus mrigala. IOSR Journal of Pharmacology and Biosciences, 9(5): 03-11.

Wu, S., Sun, A., Zhai, F., Wang, J., Xu, W., Zhang, Q. and Volinsky, A.A. 2011. Iron oxide magnetic nanoparticles synthesis from tailings by ultrasonic chemical co-precipitation. Proceedings of Engineering, 27: 632-637.

Zhu, X., Zhu, L., Chen, Y. and Tian, S. 2009. Acute toxicities of six manufactured nanomaterial suspensions to Daphnia magna. Journal of Nanoparticles Research, 11: 67-75. 